Article

\title{
Natural Regeneration after Long-Term Bracken Fern Control with Balsa (Ochroma pyramidale) in the Neotropics
}

\section{Samuel I. Levy-Tacher ${ }^{1, *}$, Ivar Vleut ${ }^{1}$, Francisco Román-Dañobeytia ${ }^{2,3}$ and James Aronson ${ }^{4,5}$}

1 El Colegio de la Frontera Sur, ECOSUR, Carr. Panamericana y Periférico Sur s/n Barrio Ma. Auxiliadora, C.P. 29290, San Cristóbal de las Casas, Chiapas, Mexico; E-Mails: slevytacher@gmail.com (S.I.L.-T.); ivar8207@gmail.com (I.V.)

2 Center for Latin American Studies, University of Florida, Gainesville, FL 32611, USA; E-Mail: fromn76@gmail.com

3 Madre de Dios Consortium, Puerto Maldonado, Madre de Dios 17001, Peru

4 Centre d'Ecologie Fonctionnelle et Evolutive (U.M.R. 5175-Campus du CNRS), 1919, Route de Mende, 34293 Montpellier, France; E-Mail: james.aronson@cefe.cnrs.fr

5 Missouri Botanical Garden, 4344 Shaw Blvd., PO Box 299, St. Louis, MO 63166-0299, USA

* Author to whom correspondence should be addressed; E-Mail: slevytacher@gmail.com; Tel.: +52-967-674-9000 (ext. 1323); Fax: +52-967-674-9021.

Academic Editors: Andrew Vayda and Eric J. Jokela

Received: 19 January 2015 / Accepted: 3 June 2015 / Published: 16 June 2015

\begin{abstract}
In many parts of the Neotropics, deforested areas are often colonized by the highly competitive invasive bracken fern (Pteridium aquilinum), which inhabits naturally regenerated forests and successional forests on abandoned farmland. Within the tropical forest region of Chiapas in southern Mexico, we implemented an experiment in 2005 to out-compete bracken fern infestation and reduce or eliminate live bracken rhizomes using several treatments: Direct sowing of balsa seeds (Ochroma pyramidale; Malvaceae), a traditional Lacandon treatment of scattering balsa seeds, transplanting balsa seedlings, and a control treatment (without balsa). For each treatment, we applied three different bracken weeding frequencies: No weeding, biweekly weeding, and monthly weeding. In this study, we present data gathered four years after establishing the experiment regarding: Bracken fern rhizome biomass, balsa density, basal area, height, density, species richness of naturally regenerating vegetation for all treatments, and bracken weeding frequencies. We also evaluated the importance of balsa and its regenerative attributes in controlling bracken fern by correlating it with remaining belowground live rhizome biomass. Living rhizome biomass
\end{abstract}


was completely eradicated in all treatments with biweekly and monthly weeding. Density and species richness of a naturally regenerated species were negatively correlated with bracken fern rhizome biomass, and the density of this species was highest in areas with no rhizome biomass. Although balsa tree stands are effective short-term solutions for controlling rhizome biomass, the success of natural regeneration following balsa establishment can be critical to long-term elimination of bracken fern.

Keywords: bracken fern eradication; direct sowing; species regeneration; transplanting; weeding

\section{Introduction}

The impact of invasive species in ecosystems and agroecosystems varies significantly depending on the type of invasive species, the extent of the invasion, and the type of ecosystem in question as well as its level of vulnerability [1]. In the past few decades, the presence of invasive species on a global level has increased due to the ease and accessibility of modern transportation, by which thousands of species have been moved to new habitats [2,3]. These species do not prosper in the same manner in all locations; rather, their levels of establishment depend on the characteristics of the receiving communities, such that environments with high levels of species richness are more resistant to invasions than those with few species [4]. Thus, diverse ecosystems are less vulnerable to invasions to the extent that they maintain a high species diversity [5]. Invasive plants can include both native and non-native species and are characterized by being able to infiltrate and dominate native flora and managed areas. They may pose a serious threat to native species richness, in addition to impacting ecosystem functioning and reducing agricultural productivity [6,7]. However, it is necessary to understand the ecological processes such as competition and natural succession in order to choose plants that may replace undesired species and assure the success of restoration efforts [8].

One of the most widely distributed invasive plant species in the world is the bracken fern (Pteridium aquilinum) [9]. This plant invades and dominates large areas of disturbed land in both temperate and tropical regions [10]. Due to its outstanding competitive ability, bracken fern (hereafter, bracken) hinders reforestation and regeneration [11,12]. Despite extensive research on bracken control [10,11], most strategies intended to control this species have been unsuccessful $[12,13]$. The main reasons for unsuccessful bracken control are its extensive rhizome system (15-20 t ha $\mathrm{ha}^{-1}$ [14-19] characterized by storage of a large quantity of carbohydrates, and its extensive network of dormant buds $[17,20]$. Furthermore, bracken contains quercetin and other chemicals that render it unpalatable and probably toxic for most herbivores [21,22]. This combination of traits allows for rapid re-growth following cold winters, dry seasons, or fire [20,23] and provides protection from cattle, rodents, and other herbivores. Bracken typically colonizes open fields after disturbance events, degrading land used for crops and animal husbandry [24] and hence affecting people's economies. Accumulation of slowly decomposing bracken fronds [25] depletes seed banks and hinders growth of seedlings, constraining the growth of natural vegetation [26] and delaying natural succession for decades or even centuries [10,12,26]. Another important trait of bracken is its capacity to endure full sunlight and grow in partially shaded areas. However, bracken is intolerant of full shade; therefore, it is possible that native species out-competes this invasive 
species [20]. Thus, the establishment of early-successional tree species that shade out the rhizomatous fern stands and allow succession to proceed seems to be the most effective low-cost management strategy for inhibiting bracken growth [24]. A strategy used by the Lacandon Mayan people of Chiapas, in southern Mexico, to counter bracken invasion is to plant balsa (Ochromapyramidale (Cav. ex Lam.) Urb. (Malvaceae)), a neotropical broad-leaved pioneer tree species that shades out and eventually kills bracken fern. Thus, traditional knowledge of local people may be a valuable source of information for dealing with this invasive species [27-29].

In October 2005, we implemented an experiment aimed at comparing the effectiveness of different techniques of overcoming bracken fern infestation (direct sowing of balsa seeds, the traditional Lacandon treatment of broadcasting balsa seeds, transplanting balsa seedlings, and a control treatment without balsa $[28,29]$ in the region of Chiapas, Mexico. We also applied different weeding frequencies (no weeding, biweekly weeding, and monthly weeding) because results of prior studies showed a significant decrease in bracken rhizome biomass in plots with weeding [15,19,28,29]. Four years after the onset of the experiment, we assessed long-term bracken eradication by quantifying rhizome biomass among the different treatments with balsa and by evaluating density, basal area, and height of balsa trees, as well as the density and richness of regenerated tree species in the understory. We expected that all treatments with weeding would completely eradicate bracken within four years and increase density and richness of naturally regenerated tree species in the understory. Finally, we expected that richness and density of naturally regenerated tree species would be positively correlated with a decrease in bracken biomass.

\section{Materials and Methods}

\subsection{Site Description}

The experiment took place in Lacanhá Chansayab, Chiapas, Mexico $\left(16^{\circ} 47^{\prime} \mathrm{N} ; 91^{\circ} 09^{\prime} \mathrm{W}\right)$. The study region borders the largest area of undisturbed tropical rainforest in Central America and has been managed by the Lacandon people for at least four centuries [30]. The site is located at 350 masl and has a mean annual precipitation of 2300-2500 mm and a mean annual temperature of $25^{\circ} \mathrm{C}$ [31]. Soils are humic acrisols [32], and the predominant natural vegetation type is tropical evergreen forest [33]. Currently, the area consists of a landscape mosaic of patches of secondary forest, mature forest, and maize fields.

\subsection{Experimental Design}

The experimental design stems from traditional use of a long fallow rotational slash-and-burn system for maize production in small clearings within tropical forests [27]. We used balsa to restore bracken-infested areas because it thrives on abandoned agricultural soils with minimal maintenance, has a survival rate of over $90 \%$, and can reach up to 6-7 $\mathrm{m}$ in height after just one year [28]. In addition, the Lacandon people use balsa to accelerate the natural regeneration process as it helps replenish fertility in nutrient-poor, degraded soils $[27,28]$.

The experimental area was previously used as an agricultural field for subsistence-level maize production. Subsequently, over a period of 30 years, it was invaded by bracken, which covered a total area of 0.8 ha. 
Invasion was so prominent that plots were only penetrable with the use of a machete, and dead bracken fronds formed a $0.5 \mathrm{~m}$ thick layer while living fronds reached over $2 \mathrm{~m}$ in height.

In October 2005, we set up a full factorial randomized block experiment in a $2304 \mathrm{~m}^{2}$ area, $(32 \times 72 \mathrm{~m})$ divided into four equal sized $576 \mathrm{~m}^{2}$ blocks $(8 \times 72 \mathrm{~m})$. Each block was separated by a $2 \mathrm{~m}$ access trail and included nine adjacent $8 \times 8 \mathrm{~m}$ plots in which three balsa-establishment methods (direct sowing of seeds, broadcasting of seeds, (traditional Lacandon treatment) and transplanting of seedlings) were crossed with three bracken weeding frequencies (no weeding, biweekly weeding, and monthly weeding) applied during the first six months of the experiment (Figure 1). Control plots (without planting balsa trees) for each of the three weeding frequencies were not included in the original design; rather, they were located in an area dominated by bracken in the direct vicinity $(<10 \mathrm{~m})$ of the four blocks (Figure 1). For statistical analyses, we included each of the respective control plots nearest the block.

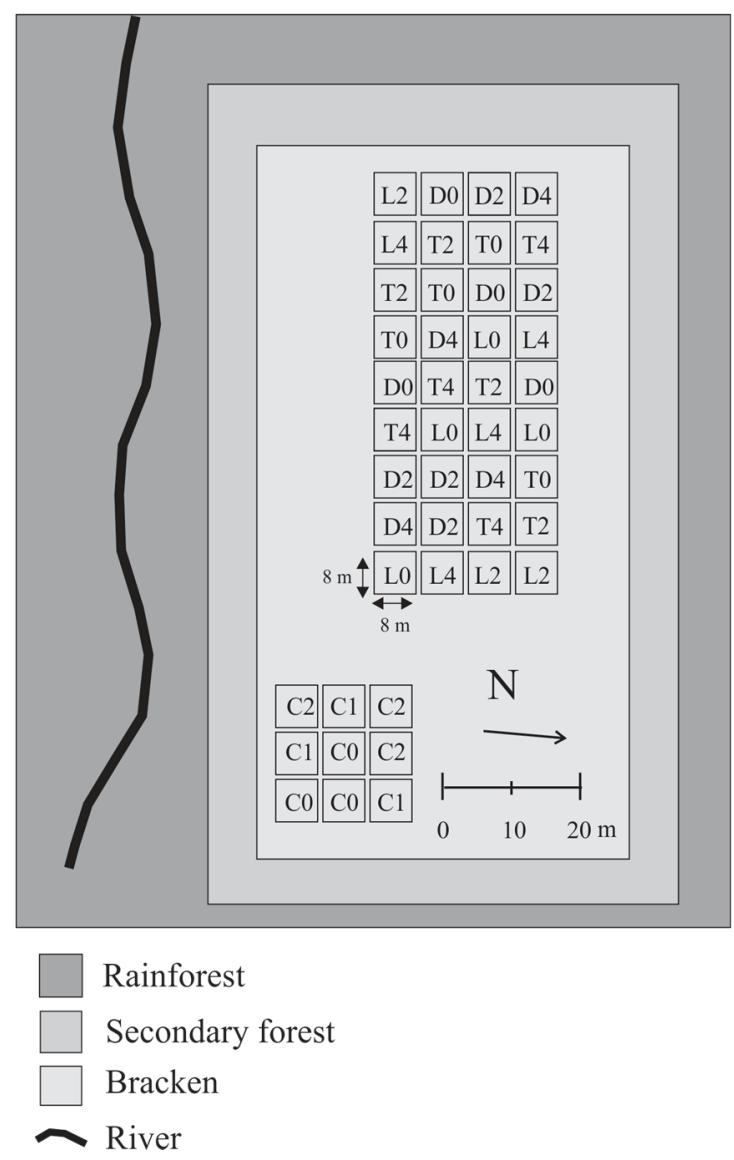

Figure 1. Spatial arrangement of treatments in the experiment, including the type of forest that covered the surroundings of the experimental area. D: Direct sowing; L: Traditional Lacandon method (broadcasting); T: Transplanting; C: Control.

Local Lacandon collaborators manually cleared the experimental area with a machete and burned it prior to establishing balsa trees. The first method consisted of directly sowing 15-20 balsa seeds at a $3 \mathrm{~cm}$ depth. As a second planting method, we mimicked the traditional Lacandon method of randomly broadcasting approximately 5000 balsa seeds per plot, which resulted in a patchy distribution of the emerging seedlings. The third method consisted of transplanting two-month-old nursery seedlings with 
a spacing of $2 \times 2 \mathrm{~m}$. No thinning was carried out during the experiment. The minimum bracken weeding frequency entailed only initial clearing of the site prior to planting or sowing, without posterior weeding.

\subsection{Living Bracken Rhizome Biomass Survey}

In a randomly assigned $0.5 \mathrm{~m}^{2}$ area, within the central $6 \times 6 \mathrm{~m}$ of each of the 12 balsa treatment plots, a hole as deep as the deepest rhizome $(\sim 0.5 \mathrm{~m})$ was excavated and live bracken rhizomes were quantified. Rhizome samples were sprayed with water to remove soil and dead rhizome fragments. For each treatment plot, the remaining live rhizome sample was oven dried at $80{ }^{\circ} \mathrm{C}$ and weighed with a digital precision scale.

\subsection{Balsa Attributes}

Four years after establishing the experiment, maximum tree height $(\mathrm{m})$ and diameter at breast height ( $\mathrm{dbh}$ in $\mathrm{cm}$ ) of balsa trees were measured. In the treatment plots, density in terms of number of individuals per square meter and basal area of surviving balsa tree individuals were estimated.

\subsection{Natural Regeneration Survey}

In each subplot $(6 \times 6 \mathrm{~m})$, we identified, recorded, and measured basal diameter $(\mathrm{cm})$ of stems of native woody regenerating species growing spontaneously after establishing the experiment. We also determined density and richness of naturally regenerated species as the number of individuals and the number of woody species per subplot, respectively. To analyze the potential facilitation effect of balsa stands in reinitiating the successional process, we classified woody regenerating species into three successional groups based on a secondary succession sequence previously documented in the study area [34]: (1) early successional, including typical pioneer species that grow in open areas; (2) mid-successional, including species that establish in open areas but which generally live longer and grow taller than species from the first group; and (3) late successional, including shade-tolerant species present in mature forests. We propose that these three groups are sufficiently distinct to merit designation as functional groups [35,36] and to be considered complementary to the restoration process [37].

\subsection{Statistical Analysis}

We used Generalized Linear Mixed Models (GLMMs) to analyze the effects of: (1) weeding; (2) balsa-establishing treatments; and (3) the interaction of weeding and balsa on bracken rhizome biomass, balsa attributes (tree height, basal area, and density), and natural regeneration attributes (density and species richness). Blocks were included as a random effect, and treatments were considered as fixed effects. To comply with normality assumptions prior to analysis, data on bracken rhizome biomass, balsa density, and basal area were log 10-transformed. We constructed residual plots for each model in order to check for normality and comply with GLMM requirements. We used a Bonferroni post-hoc test to analyze differences among treatments and weeding intensities within each dependent variable.

We constructed a partial matrix of correlation coefficients from a Spearman partial-correlation to determine the relationship among rhizome biomass, $O$. pyramidale, and regeneration attributes, adjusting for 
the remaining predictor variables. All $p$ values are two-tailed, and $p$ values below 0.05 were considered to indicate a significant correlation. All analyses were performed with IBM SPSS, version 20.0 [38].

\section{Results}

\subsection{Rhizome Biomass}

We found that different balsa planting methods $\left(F_{3,384}=34.92, p<0.01\right)$, weeding $\left(F_{2,384}=594.55\right.$, $p<0.01)$, and the combination of planting method and weeding $\left(F_{6,268}=81.54, p<0.01\right)$ reduced bracken rhizome biomass. In contrast, direct sowing, the Lacandon treatment without weeding, and the control treatments exhibited the highest rhizome biomass (Figure 2).

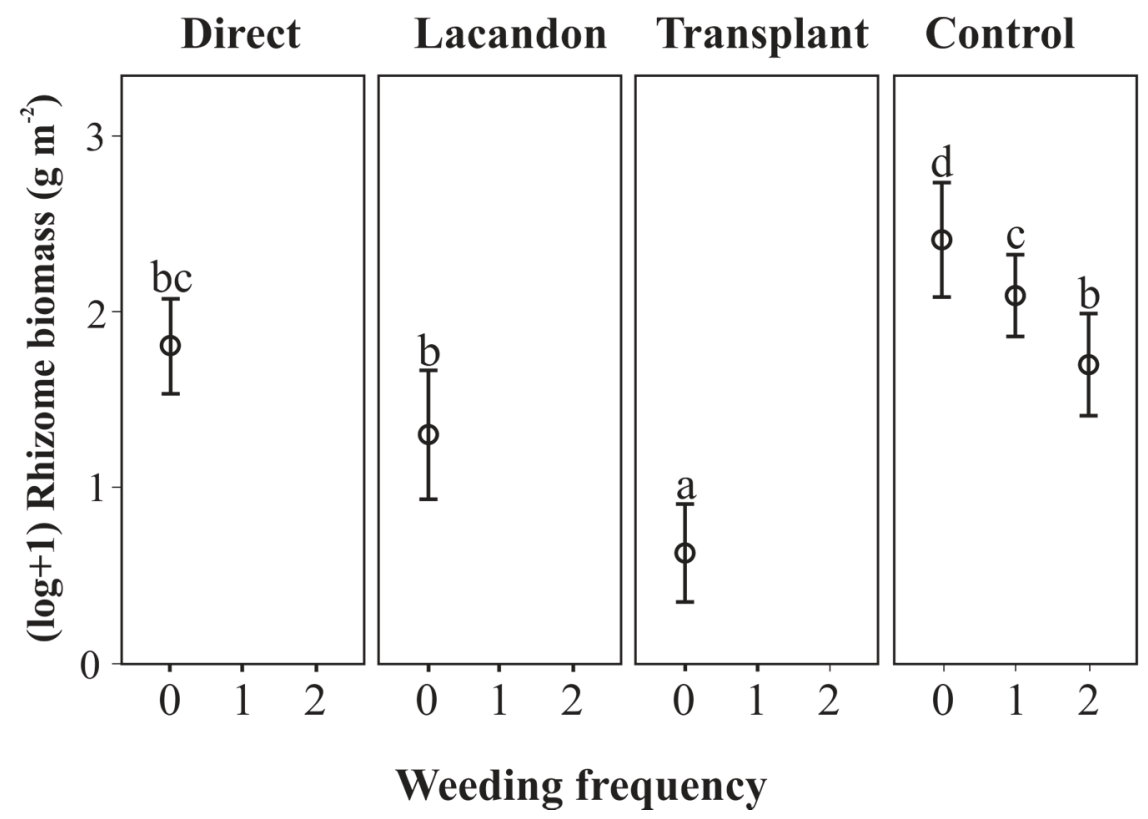

Figure 2. Bracken fern biomass $(\log +1)$ mean and $95 \%$ confidence intervals $\left(\mathrm{g} \mathrm{m}^{-2}\right)$ per treatment and weeding intensity $(0=$ no weeding; $1=$ monthly weeding; and $2=$ biweekly weeding) assessed four years after establishing the treatments. Different letters indicate significant differences in rhizome biomass among treatments and weeding frequencies, as assessed by a Bonferroni post-hoc test.

\subsection{Balsa Attributes}

All balsa attributes were significantly related to treatment, weeding frequency, and the interaction between treatment and weeding frequency, with the exception of balsa density and weeding frequency (Table 1). Height (Figure 3A) and basal area of balsa individuals (Figure 3B) increased with the transplanted treatment and weeding frequency. Density of balsa was lowest in direct sowing of seeds and Lacandon treatments without weeding and highest in the transplanted treatment, with no difference due to frequency of weeding (Figure 3C). 
Table 1. Results of the Generalized Linear Mixed Models for the effect of the balsa treatment, weeding treatment, and the interaction between the two on balsa attributes (height, basal area, and density) and regeneration attributes (density and richness), including block as a random effect.

\begin{tabular}{|c|c|c|c|c|c|c|}
\hline & \multicolumn{2}{|c|}{ Treatment } & \multicolumn{2}{|c|}{ Weeding } & \multicolumn{2}{|c|}{ Weeding*Treatment } \\
\hline & $F_{2,384}$ & $p$ Value & $F_{2,384}$ & $p$ Value & $F_{2,384}$ & $p$ Value \\
\hline \multicolumn{7}{|c|}{ O. pyramidale } \\
\hline Height $(\mathrm{cm})$ & 106.84 & $<0.001$ & 43.88 & $<0.001$ & 10.46 & $<0.001$ \\
\hline Basal area & 35.125 & $<0.001$ & 40.02 & $<0.001$ & 5.011 & $<0.001$ \\
\hline Density & 52.939 & $<0.001$ & 0.029 & 0.923 & 18.52 & $<0.001$ \\
\hline \multicolumn{7}{|c|}{ Regeneration } \\
\hline Density & 179.71 & $<0.001$ & 132.907 & 0.001 & 14.49 & $<0.001$ \\
\hline Richness & 113.43 & $<0.001$ & 48.12 & $<0.001$ & 3.39 & $<0.001$ \\
\hline
\end{tabular}

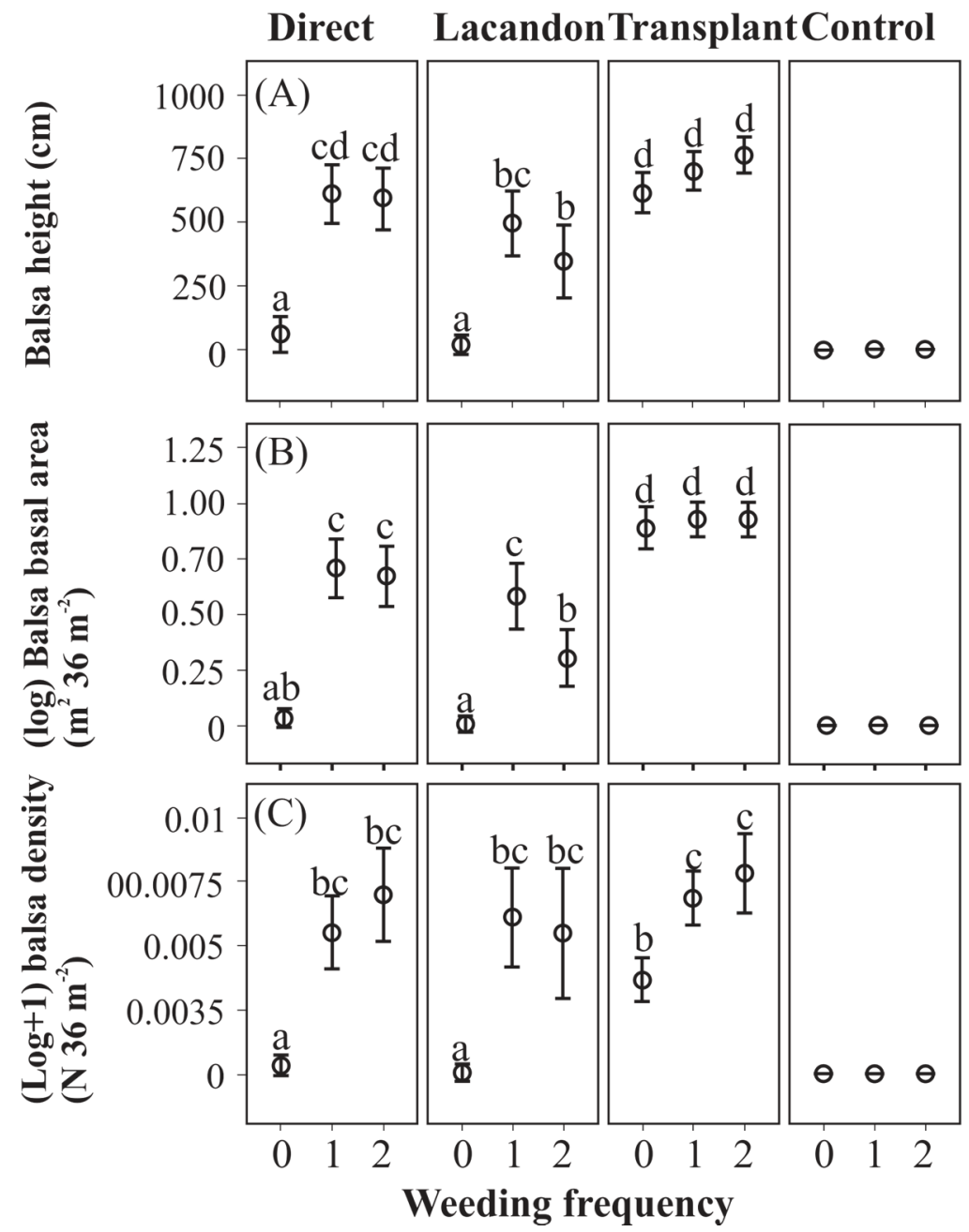

Figure 3. (A) Mean and 95\% confidence interval of balsa (Ochroma pyramidale) tree height $(\mathrm{cm})$; (B) basal area $\left(36 \mathrm{~m}^{-2}\right)$; and $(\mathbf{C})$ density $\left(36 \mathrm{~m}^{-2}\right)$ per treatment and weeding intensity $(0$ = no weeding; 1 = monthly weeding; and 2 = biweekly weeding $)$, as assessed four years after establishing treatments. Different letters indicate differences in balsa tree height among treatments and weeding frequencies, as assessed by a Bonferroni post-hoc test. 


\subsection{Natural Regeneration Attributes}

Four years after setting up the experiment, the experimental area had been colonized by 711 stems corresponding to 33 woody plant species. Among these, 23 species were trees, nine were shrubs, and one was unknown. The majority of recorded vegetation species (39) were early-successional species (mean $\pm \mathrm{SD}, 9.5 \pm 3.6$ ), followed by mid-successional (7; mean $\pm \mathrm{SD}, 2.7 \pm 1.8$ ) and late-successional species $(2 ;$ mean $\pm \mathrm{SD}, 0.67 \pm 0.47)$ (Table 2).

Table 2. Density of woody plant species, growth form (tree or shrub), and successional stage in experimental plots $\left(36 \mathrm{~m}^{2}\right)$ previously dominated by bracken (Pteridium aquilinum).

\begin{tabular}{|c|c|c|c|}
\hline Species, Authors, and Family * & $\begin{array}{l}\text { Growth } \\
\text { Form * }\end{array}$ & $\begin{array}{c}\text { Successional } \\
\text { Stage } * *\end{array}$ & $\begin{array}{c}\text { Total Ind. } \\
\left(36 \mathrm{~m}^{2}\right)\end{array}$ \\
\hline Piper aduncum, L., Piperaceae & shrub & ES & 210 \\
\hline Euphorbia sp., Euphorbiacea & _- & ES & 192 \\
\hline Piper auritum, Kunth., Piperaceae & shrub & ES & 104 \\
\hline Podachaenium eminens, Benth. ex Oerst., Astereceae & shrub & ES & 30 \\
\hline Bursera simaruba, (L.) Sarg., Burseraceae & tree & ES & 29 \\
\hline Swietenia macrophylla, King, Meliaceae & tree & MS & 24 \\
\hline Spondias mombin, L., Anacardiaceae & tree & MS & 23 \\
\hline Platymiscium dimorphandrum, Donn. Sm., Fabaceae & tree & MS & 17 \\
\hline Cecropia obtusifolia, Bertol., Cecropiaceae & tree & ES & 14 \\
\hline Heliocarpus appendiculatus, Turcz., Tiliaceae & tree & ES & 11 \\
\hline Clibadium arboreum, Donn. Sm., Asteraceae & tree & ES & 10 \\
\hline Schizolobium parahyba, (Vell.) S.F. Blake, Fabaceae & tree & ES & 9 \\
\hline Sapium lateriflorum, Hemsl., Euphorbiaceae & tree & LS & 4 \\
\hline Hamelia patens, Jacq., Rubiaceae & shrub & ES & 4 \\
\hline Solanum erianthum, D. Don., Solanaceae & tree & ES & 4 \\
\hline Tabernaemontana amygdalifolia, Jacq., Apocynaceae & tree & MS & 2 \\
\hline Ardisia paschalis, Donn. Sm., Myrsinaceae & tree & MS & 2 \\
\hline Citrus nobilis, Loureiro, Rutaceae & tree & ES & 2 \\
\hline Ochroma pyramidale, (Cav. ex. Lam.) Urb., Bombacaceae & tree & ES & 2 \\
\hline Leucaena macrophylla, Benth., Fabaceae & shrub & ES & 2 \\
\hline Trophis racemosa, (L.) Urb., Moraceae & tree & ES & 2 \\
\hline Guarea grandifolia, C. DC., Meliaceae & tree & ES & 2 \\
\hline Chionanthus oblanceolatus, (B.L. Rob.) P.S. Green, Oleaceae & tree & ES & 2 \\
\hline Ficus maxima, Mill., Moraceae & tree & MS & 1 \\
\hline Castilla elastica, Sessé ex Cerv., Moraceae & tree & MS & 1 \\
\hline Ceiba pentandra, (L.) Gaertn., Malvaceae & tree & LS & 1 \\
\hline Acacia mayana, Lundell, Fabaceae & tree & ES & 1 \\
\hline Eupatorium pittieri, Klatt, Asteraceae & shrub & ES & 1 \\
\hline Saurauia yasicae, Loes., Actinidaceae & shrub & ES & 1 \\
\hline Wimmeria concolor, Schltdl. \& Cham., Celastraceae & tree & ES & 1 \\
\hline Senna fruticosa, (Mill.) H.S. Irwin \& Barneby., Fabaceae & shrub & ES & 1 \\
\hline Solanum sp., Solanaceae & shrub & ES & 1 \\
\hline Trema micrantha (L.) Blume (Ulmaceae) & tree & ES & 1 \\
\hline Total & & & 711 \\
\hline
\end{tabular}

*: [39] Pennington and Sarukhán (2005); **: Adapted from [34] Levy-Tacher and Aguirre-Rivera (2005); $\mathrm{ES}=$ early-successional; LS = late-successional; MS = mid-successional. 
Density of naturally regenerating species was lowest in the control treatment and in the direct and Lacandon treatments without weeding, and highest in treatments with at least one weeding frequency (Figure 4A). Richness of naturally regenerating species was lowest in the control and Lacandon treatments without weeding, and highest in direct and transplanted treatments in all frequencies weeding (Figure 4B).

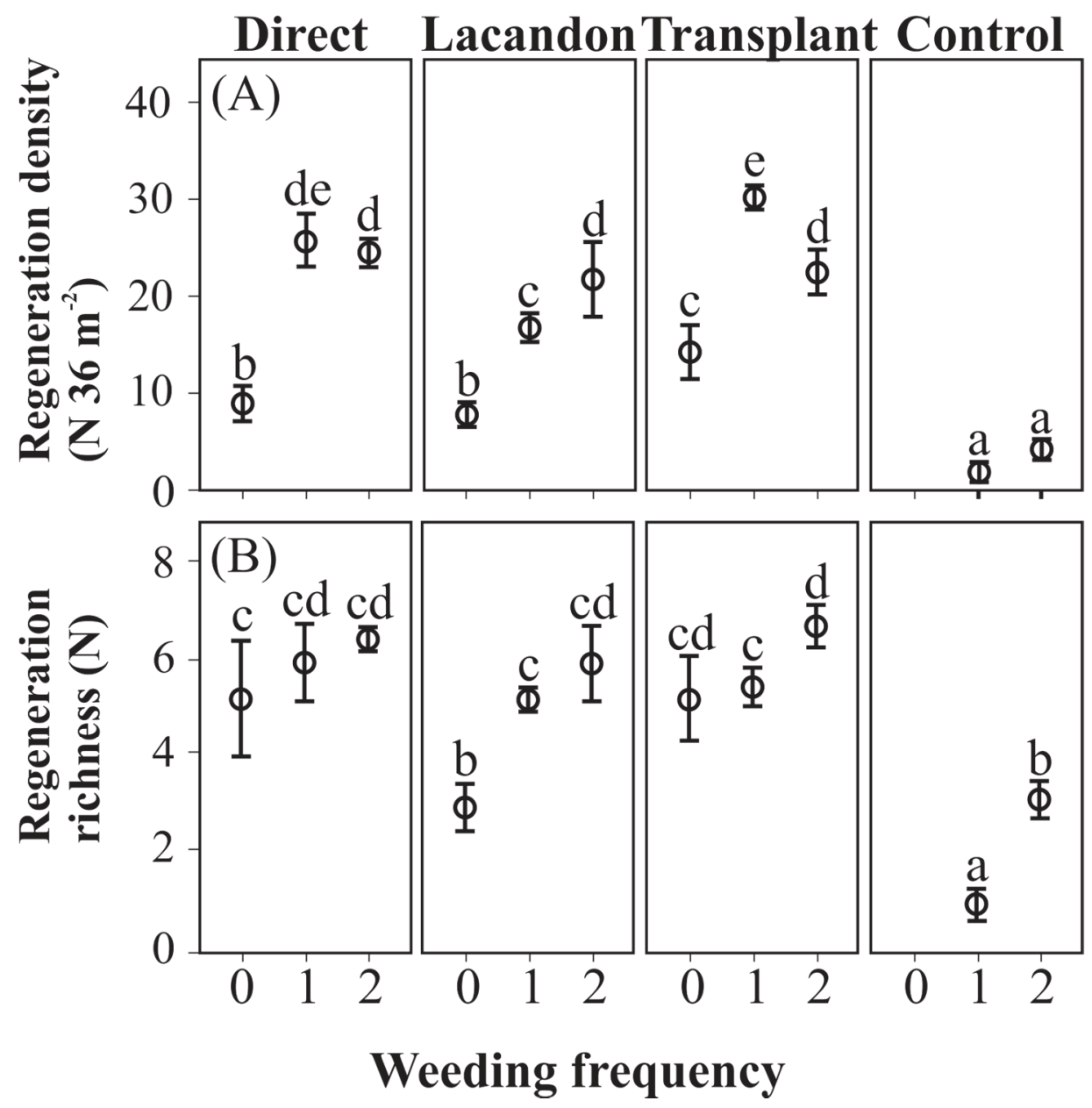

Figure 4. Mean and 95\% confidence intervals for (A) regeneration density $\left(36 \mathrm{~m}^{-2}\right)$ and (B) species richness per treatment and weeding intensity $(0=$ no weeding; $1=$ monthly weeding; and 2 = biweekly weeding) as assessed four years after establishing treatments. Different letters indicate differences in regeneration density among treatments and weeding frequencies, based on a Bonferroni post-hoc test.

\subsection{Correlation among Bracken Rhizome Biomass, Balsa Establishment Treatment, and Natural Regeneration}

Balsa density was positively correlated with balsa height and basal area, and balsa height was positively correlated with balsa basal area; however, none of these parameters were correlated with live bracken rhizome biomass (Table 3). Natural regeneration density and richness were positively correlated with each other, and negatively correlated with live bracken rhizome biomass. 
Table 3. Spearman partial correlation coefficients among bracken rhizome biomass, Ochroma pyramidale attributes (height, basal area, and density), and regeneration attributes (density and species richness) after controlling for the correlated effects of other predictor variables. $\dagger: p<0.01, \dagger: p<0.05$.

\begin{tabular}{lccccccc}
\hline & \multirow{2}{*}{ Rhizome Biomass } & \multicolumn{3}{c}{ O. pyramidale } & \multicolumn{2}{c}{ Regeneration } \\
\cline { 3 - 7 } & & Height & Basal Area & Density & Density & Richness \\
\hline \multirow{3}{*}{ O. pyramidale } & Height & -0.539 & - & & & & \\
& Basal area & -0.556 & $0.959 \ddagger$ & - & & & \\
& Density & -0.515 & $0.835 \ddagger$ & $0.828 \ddagger$ & - & & \\
\multirow{2}{*}{ Regeneration } & Density & $-0.710 \ddagger$ & 0.539 & 0.554 & 0.523 & - & \\
& Richness & $-0.634 \dagger$ & 0.464 & 0.486 & 0.473 & $0.813 \ddagger$ & - \\
\hline
\end{tabular}

\section{Discussion}

Invasive species may be controlled or even eliminated by gathering detailed information on their successional development performance, in addition to accurate planning, consulting local and traditional knowledge on natural resource management, and prevention of re-invasion. In tropical ecosystems, pioneer tree species are of particular interest in biological control of bracken, owing to their ability to aggressively out-compete colonizing light-demanding weeds and trigger forest succession [8]. Inhibition by other vegetation is a strategy commonly used for bracken control throughout the world; according to this strategy, managers aim to control dense bracken by replacing it with another type of vegetation $[15,17,40]$. In order to control invasive species, it is important to eliminate the threat before it has time to dominate and become widespread. However, in areas where invasive species have colonized ecosystems, and in which they are found in high densities and have not been sufficiently controlled, it can be helpful to understand ecological processes such as competition and natural succession of the species present in order to develop responsible management practices for eradicating or controlling invasion. The bracken fern is a very common and widely distributed invasive species that has been insufficiently controlled in temperate and tropical regions. In Chiapas, Mexico, where this study took place, at least $360 \mathrm{~km}^{2}$ (5\% of state territory) is dominated by bracken [41]. This plant is capable of colonizing areas following fires, deforestation, and agricultural activities [42] and is easily spread throughout the year due to a continual dispersion of spores.

Most research regarding bracken eradication has been conducted in temperate regions, especially in the United Kingdom $[16,43,44]$. These studies have suggested that it is not possible to eradicate the fern even after 18 years of continual harvesting [16]. However, there has been evidence of successful eradication of bracken fern in pine and other forest plantations in temperate and subtropical areas by using glyphosate and other herbicides [45-47].

In tropical regions, however, no long-term bracken-control strategy has been proposed to date. Nevertheless, Slocum et al. [48] determined that it was possible to control a similar invasive species, the cosmopolitan fern Dicranopteris pectinata in the Dominican Republic via annual clearing, removal of rhizome biomass, and planting rapidly-growing trees that promote natural regeneration of native plants. In Madagascar, similar experiments with Dicranopteris spp. are also underway (J. Aronson et al., unpublished data). Data collected after 18 months showed high levels for density, basal area and height 
of balsa trees and a significant reduction in living rhizome biomass for all treatments with bracken weeding. Furthermore, rhizome biomass was negatively correlated with balsa basal area, leaf litter, and light intensity in the understory [29]. In our study, we achieved total eradication of this invasive fern in all treatments (direct sowing of seeds, broadcasting of seeds, transplanting of seedlings and control) four years after initiating the experiment. This is the first report of successful, short-term complete bracken eradication of bracken by using fast-growing trees in tropical regions.

One year after initiating the experiment, all treatments except transplanting required bracken weeding to ensure survival of balsa seedlings [29]. In contrast, four years after initiating the experiment, there was no correlation among balsa performance, native woody species regeneration and bracken fern abundance. Thus, balsa trees with at least one weeding reached similar basal areas and heights, generating a homogeneous condition in which regeneration (density and richness) of native species and rhizomes biomass did not differ. Similarly, the effect of balsa after 18 months on rhizome biomass allowed for establishing natural regeneration beneath the balsa trees. This was illustrated by a high density and richness of natural regenerated species in all weeding treatments except for the control treatment and a negative correlation between rhizome biomass and density and richness of regenerated species after four years, as was hypothesized. The most common species that colonized our experimental area were Piper aduncum, Piper auritum, Podachaenium eminens, and Clibadium arboreum, which are indicator species of frequent, prolonged land use [34]. Another group of recruited species (Swietenia macrophylla, Platymiscium dimorphandrum, and Spondias mombin) generally occur in more advanced stages of succession [34].

Given these results, we highly recommend balsa as a species that aids in restoring and rehabilitating areas invaded by bracken fern. The proximity of restoration areas to secondary forest areas $(<100 \mathrm{~m})$ is critical to assure successful natural regeneration, as forests are seed sources for early- and mid -successional plant species [49]. In isolated locations far removed from mature forest areas, direct sowing or planting of late-successional trees in the understory of balsa can be an effective strategy for enhancing natural regeneration [50].

In summary, balsa should be considered as a feasible option for short-term forest restoration in tropical America, as well as in other tropical areas in which bracken or other rhizomatous ferns obstruct this process, and in which conditions are favorable to balsa growth. However, potential consequences of introducing non-native plants, especially fast-growing ones, should be carefully evaluated. Thus, balsa should be used with caution for restoring areas in which it is not native, although it poses a low risk given its rapid growth and relatively short life cycle (15 years), after which it tends to be replaced by other species [51]. Use of glyphosate in tropical regions for eradication of bracken ferns is another option. This alternative, in addition to manual excavation of bracken fern rhizomes, can be used to remove bracken fern for long enough to introduce native tree species.

\section{Conclusions}

The methods of forest restoration tested here may be transferable to other Neotropical regions for purposes ranging from economic and ecological rehabilitation of farmland to restoration of native forest ecosystems. Planting balsa controlled bracken fern, a high-impact invasive species, and facilitated species regeneration. We showed that only after four years were we completely able to eliminate living 
rhizome biomass of bracken fern with several balsa tree planting treatments and additional weeding. At the same time, reduced fern rhizome biomass resulted in an increase in density and species richness of naturally regenerated species in the understory of balsa trees. Finally, we also demonstrated the usefulness of traditional ecological knowledge for restoration of degraded areas. In particular, the Lacandon method of direct sowing of balsa seeds and weeding saves the effort of producing nursery plants, and therefore appears to be the most cost-effective strategy for restoring fern-dominated Neotropical forests.

\section{Acknowledgments}

We thank Manuel Castellanos Chan'kin, Adolfo Chan'kin, Antonio Sánchez González, and Miguel Angel Villatoro Juárez for technical field support, and Ann Greenberg for style corrections. This research was funded by the Instituto Nacional de Ecología y Cambio Climático (INECC), Etnobiología para la Conservación A.C. and El Colegio de la Frontera Sur (ECOSUR). We did not receive funds to publish in open access.

\section{Author Contributions}

Samuel I. Levy-Tacher, Ivar Vleut, Francisco Román-Dañobeytia and James Aronson designed the experiments; Samuel I. Levy-Tacher, Ivar Vleut and Francisco Román-Dañobeytia carried them out; Ivar Vleut analyzed the data; Samuel I. Levy-Tacher contributed tools of analysis; Samuel I. Levy-Tacher, Ivar Vleut and Francisco Román-Dañobeytia wrote the paper.

\section{Conflicts of Interest}

The authors declare no conflict of interest.

\section{References}

1. Kettunen, M.; Genovesi, P.; Gollasch, S.; Pagad, S.; Starfinger, U.; Brink, P.T.; Shine, C.C. Technical Support to EU Strategy on Invasive Species (IAS) - Assessment of the Impacts of IAS in Europe and the EU; Institute for European Environmental Policy (IEEP): Brussels, Belgium, 2008.

2. Lodge, D. Biological invasions: Lessons for ecology. Trends. Ecol. Evol. 1993, 8, 133-137.

3. Dukes, J.S.; Mooney, H.A. Disruption of ecosystem processes in western North America by invasive species. Rev. Chil. Hist. Nat. 2004, 77, 411-437.

4. Elton, C. The Ecology of Invasions by Animals and Plants; Methuen: London, UK, 1958.

5. Ricciardi, A. Facilitative interactions among aquatic invaders: Is an 'invasional meltdown' occurring in the Great Lakes? Can. J. Fish. Aquat. Sci. 2002, 58, 2513-2525.

6. Vitousek, P.M.; D’Antonio, C.M.; Loope, L.L.; Rejmanek, M.; Westbrooks, R. Introduced species: A significant component of human-caused global change. N. Z. J. Ecol. 1997, 21, 1-16.

7. Pyšek, P.; Richardson, D.M. Invasive species, environmental change and management, and health. Annu. Rev. Environ. Resour. 2010, 35, 25-55.

8. Lamb, D.; Erskine, P.D.; Parrotta, J.A. Restoration of degraded tropical forest landscapes. Science 2005, 310, 1628-1632. 
9. Taylor, J.A. The bracken problem: A global perspective. AIAS Occas. Publ. 1990, 40, 3-19.

10. Marrs, R.H.; le Duc, M.G.R.; Mitchell, J.; Goddard, D.; Paterson, S.; Pakeman, R.J. The ecology of bracken: Its role in succession and implications for control. Ann. Bot. 2000, 85, 3-15.

11. Humphrey, J.W.; Swaine, M.D. Factors affecting the natural regeneration of Quercus in Scottish oakwood. I. Competition from Pteridium aquilinum. J. Appl. Ecol. 1997, 34, 577-584.

12. Levy-Tacher, S.I.; Peña, C.B. Metabolitos secundarios y alelopatía. Acta Cient. Potos. 1999, 14, 36-65.

13. Braid, K.W. Bracken: A Review of the Literature; Commonwealth Agricultural Bureaux: Hurley, Berkshire, UK, 1959.

14. Williams, G.H. Bracken Control: A Review of Progress, 1974-1979; West of Scotland Agriculture College: Auchincruive, UK, 1980.

15. Lowday, J.E.; Marrs, R.H. Control of bracken and the restoration of heathland. I. Control of the bracken. J. Appl. Ecol. 1992, 29, 195-203.

16. Marrs, R.H.; Johnson, S.W.; le Duc, M.G. Control of bracken and restoration of heathland. VI. The response of bracken fronds to 18 years of continued bracken control or 6 years of control followed by recovery. J. Appl. Ecol. 1998, 35, 479-490.

17. Lowday, J.E. A comparison of the effects of cutting with those of the herbicide Asulam on the control of bracken (Pteridium aquilinum (L.) Kuhn). In Bracken: Ecology, Land Use and Control Technology; Smith, R.T., Taylor, J.A., Eds.; Parthenon Press: Carnforth, UK, 1986; pp. 359-367.

18. Kirkwood, R.C.; Archibald, L. The rhizome as a target site for the control of bracken using foliage-applied herbicides. In Bracken: Ecology, Land Use and Control Technology; Smith, R.T., Taylor, J.A., Eds.; Parthenon Press: Carnforth, UK, 1986; pp. 341-350.

19. Marrs, R.H.; Johnson, S.W.; le Duc, M.G.R. Control of bracken and the restoration of heathland. VII. The response of rhizomes to 18 years of continued bracken control or 6 years of control followed by recovery. J. Appl. Ecol. 1998, 35,748-757.

20. Paterson, S.; Pakeman, R.J.; Marrs, R.H. Evaluation of a bracken (Pteridium aquilinum (L.) Kuhn) growth modeling predicting the effects of control strategies a cross a range of climatic zones in Great Britain. Ann. Appl. Biol. 1997, 130, 305-318.

21. Mahir-Pamukcu, A.; Yalçiner, S.; Hatcher, F. Quercetin, a rat intestinal and bladder carcinogen present in bracken fern (Pteridium aquilinum). Cancer Res. 1980, 40, 3468-3472.

22. Saveria-Campo, M.; Jarrett, M.; Barron, R.; O’Neil, B.W.; Smith, K.T. Association of bovine papillomavirus type 2 and bracken fern with bladder cancer in cattle. Cancer Res. 1992, 52, 6898-6904.

23. Pakeman, R.J.; Marrs, R.H. Long-term recovery of bracken (Pteridium aquilinum (L.) Kuhn) after asulam spraying. Ann. Appl. Biol. 1993, 122, 519-530.

24. Schneider, L.; Goeghegan, J. Land abandonment in an agricultural frontier after a plant invasion: The case of bracken fern in Southern Yucatan, Mexico. Agric. Resour. Econ. Rev. 2006, 35, 167-177.

25. Frankland, J.C. Decomposition of bracken litter. Bot. J. Linn. Soc. 1976, 73, 133-143.

26. Da Silva, U.D.S.R.; Silva-Matos, D.M.D. The invasion of Pteridium aquilinum and the impoverishment of the seed bank in fire areas of Brazilian Atlantic Forest. Biodivers. Conserv. 2006, 15, 3035-3043.

27. Levy-Tacher, S.I.; Golicher, J.D. How predictive is traditional ecological knowledge? The case of the Lacandon Maya fallow enrichment system. Interciencia 2004, 29, 496-503. 
28. Douterlungne, D.; Levy-Tacher, S.I.; Golicher, J.D.; Román-Dañobeitya, F. Applying Indigenous knowledge to the restoration of degraded tropical rain forest dominated by bracken. Restor. Ecol. 2010, 18, 322-329.

29. Douterlungne, D.; Thomas, E.; Levy-Tacher, S.I. Fast-growing pioneer tree stands as a rapid and effective strategy for bracken elimination in the Neotropics. J. Appl. Ecol. 2013, 50, 1257-1265.

30. De Vos, J. Oro verde: La Conquista de La Selva Lacandona Por Los Madereros Tabasqueños, 1822-1949; Instituto de Cultura de Tabasco/Fondo de Cultura Económica: Villa Hermosa, Tabasco, Mexico, 1988.

31. Instituto Nacional de Estadística Geografía e Informática (INEGI). Carta Magnética de Campo Total Las Margaritas E15-12-D15-3, Chis., Esc. 1:250,000; Consejo de Recursos Minerales: Pachuca, Hidalgo, México, 2006.

32. Anonymous. Estudio de gran Visión de la zona Lacandona, Chiapas; Comisión de Estudios del Territorio Nacional, Secretaría de la Presidencia: Distrito Federal, Mexico, 1974.

33. Rzedowski. J. Vegetación de México; Limusa: Distrito Federal, Mexico, 1978.

34. Levy-Tacher, S.I.; Aguirre, J.R.R. Successional pathways derived from different vegetation use patterns by Lacandon Mayan Indians. J. Sustain. Agric. 2005, 26, 49-82.

35. Whitmore, T.C. Canopy gaps and the two major groups of forest trees. Ecology 1989, 70, 536-538.

36. Guariguata, M.; Ostertag, R. Neotropical secondary forest succession: Changes in structural and functional characteristics. For. Ecol. Manag. 2001, 148, 185-206.

37. Rodrigues, R.R.; Lima, R.A.F.; Gandolfi, S.; Nave, A.G. On the restoration of high diversity forests: 30 years of experience in the Brazilian Atlantic Forest. Biol. Conserv. 2009, 142, 1242-1251.

38. IBM SPSS. “IBM SPSS Statistics Base 20”; SPSS Inc.: Chicago, IL, USA, 2011.

39. Pennington, T.D.; Sarukhán, J. Manual para la identificación de campo de los principales árboles tropicales de México; Instituto Nacional de Investigaciones Forestales, SAG: Distrito Federal, México, 1968.

40. Le Duc, M.G.; Pakeman, R.J.; Marrs, R.H. Changes in the rhizome system of bracken subjected to long-term experimental treatment. J. Appl. Ecol. 2003, 40, 508-522.

41. Suazo, I. Aspectos ecológicos de la especie invasora Pteridium aquilinum L. Kuhn en una selva húmeda de la región de Chajul, Chiapas, Mexico, Ph.D. Thesis, Universidad Michoacana de San Nicolas de Hidalgo, Morelia, Michoacán, México, 1998.

42. Page, C.N. The strategies of bracken as a permanent ecological opportunist. In Bracken: Ecology, Land Use and Control Technology; Parthenon: Carnforth, UK, 1986; pp. 173-181.

43. Lowday, J.E. The effects of cutting and Asulam on the frond and rhizome characteristics of bracken (Pteridium aquilinum (L.) Kuhn). Asp. Appl. Biol. 1984, 5, 275-282.

44. Maren, I.E.; Vandvik, V.; Ekelund, K. Restoration of bracken-invaded Calluna vulgaris Heathlands: Effects on vegetation dynamics and non-target species. Biol. Conserv. 2008, 141, 1032-1042.

45. Karjalainen, U.; Boomsma, D. Bracken fern control for radiata pine plantations in South Australia. Aust. For. 1989, 52, 37-44.

46. McDonald, P.M.; Abbott, C.S.; Fiddler, G.O. Density and development of Bracken Fern (Pteridium aquilinum) in forest plantations as affected by manual and chemical application. Nativ. Plants J. 2003, 4, 52-60. 
47. Roos, K.; Rödel, H.G.; Beck, E. Short-and long-term effects of weed control on pastures infested with Pteridium arachnoideum and an attempt to regenerate abandoned pastures in South Ecuador. Weed Res. 2011, 51, 165-176.

48. Slocum, M.G.; Aide, T.M.; Zimmerman, J.K.; Navarro, L. A strategy for restoration of montane forest in anthropogenic fern thickets in the Dominican Republic. Restor. Ecol. 2006, 14, 526-536.

49. Chazdon, R.L. Tropical forest recovery: Legacies of human impact and natural disturbances. Perspect. Plant Ecol. Evol. Syst. 2003, 6, 51-71.

50. Cole, R.J.; Holl, K.D.; Keene, C.L.; Zahawi, R.A. Direct seeding of late-successional trees to restore tropical montane forest. For. Ecol. Manag. 2010, 261, 1590-1597.

51. Vleut, I.; Levy-Tacher, S.I.; de Boer, F.; Galindo-González, J.; Ramírez-Marcial, N. Can a fast-growing early successional tree (Ochroma pyramidale, Malvaceae) accelerate forest succession? J. Trop. Ecol. 2013, 29, 173-180.

(C) 2015 by the authors; licensee MDPI, Basel, Switzerland. This article is an open access article distributed under the terms and conditions of the Creative Commons Attribution license (http://creativecommons.org/licenses/by/4.0/). 